\title{
Modified Spirulina maxima Pectin Nanoparticles Improve the Developmental Competence of In Vitro Matured Porcine Oocytes
}

\author{
Pantu-Kumar Roy ${ }^{1}{ }^{\mathbb{D}}$, Ahmad-Yar Qamar ${ }^{1,2} \mathbb{1}$, Bereket-Molla Tanga ${ }^{1,3}$, Seonggyu Bang ${ }^{1}$, Gyeonghwan Seong ${ }^{1}$, \\ Xun Fang ${ }^{1}$, Ghangyong Kim ${ }^{1}$, Shan-Lakmal Edirisinghe ${ }^{1}{ }^{\circledR}$, Mahanama De Zoysa ${ }^{1}{ }^{\circledR}$, Do-Hyung Kang ${ }^{4,5}$,

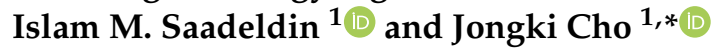

1 College of Veterinary Medicine, Chungnam National University, Daejeon 34134, Korea; vetpantu88@gmail.com (P.-K.R.); ahmad.qamar@uvas.edu.pk (A.-Y.Q.); tanga@o.cnu.ac.kr (B.-M.T.); bangsk97@o.cnu.ac.kr (S.B.); 202050377@o.cnu.ac.kr (G.S.); fx2442@o.cnu.ac.kr (X.F.); gykim1007@gmail.com (G.K.); shan.lakmal09011@gmail.com (S.-L.E.); mahanama@cnu.ac.kr (M.D.Z.); islamms@zu.edu.eg (I.M.S.)

2 Department of Clinical Sciences, College of Veterinary and Animal Sciences, Jhang 35200, Pakistan

3 Faculty of Veterinary Medicine, Hawassa University, Hawassa 05, Ethiopia

4 Jeju Marine Research Center, Korea Institute of Ocean Science and Technology (KIOST), Jeju 63349, Korea; dohkang@kiost.ac.kr

5 Department of Ocean Science, University of Science and Technology (UST), Jeju 63349, Korea

check for

updates

Citation: Roy, P.-K.; Qamar, A.-Y.; Tanga, B.-M.; Bang, S.; Seong, G.; Fang, X.; Kim, G.; Edirisinghe, S.-L.; De Zoysa, M.; Kang, D.-H.; et al. Modified Spirulina maxima Pectin Nanoparticles Improve the Developmental Competence of In Vitro Matured Porcine Oocytes. Animals 2021, 11, 2483. https:// doi.org/10.3390/ani11092483

Academic Editors:

Antonio Gonzalez-Bulnes and Nesreen Hashem

Received: 13 July 2021

Accepted: 20 August 2021

Published: 24 August 2021

Publisher's Note: MDPI stays neutral with regard to jurisdictional claims in published maps and institutional affiliations.

Copyright: (c) 2021 by the authors. Licensee MDPI, Basel, Switzerland. This article is an open access article distributed under the terms and conditions of the Creative Commons Attribution (CC BY) license (https:// creativecommons.org/licenses/by/ $4.0 /)$.
* Correspondence: cjki@cnu.ac.kr; Tel.: +82-42-821-6788

Simple Summary: Poor in vitro embryo development is a major obstacle in porcine assisted reproduction. In the current study, we utilized modified Spirulina maxima pectin nanoparticles as a supplement to improve porcine in vitro maturation medium. Results showed that modified Spirulina maxima pectin nanoparticles at $2.5 \mu \mathrm{g} / \mathrm{mL}$ improved oocyte maturation in form of first polar body extrusion, reduced oxidative stress, and increased the developmental competence of the oocytes after parthenogenetic activation and somatic cell nuclear transfer. Moreover, the relative transcripts quantification showed significant increase in the pluripotency-associated transcripts in the resultant cloned embryos after modified Spirulina maxima pectin nanoparticles supplementation. Therefore, we provide an optimum in vitro maturation condition to improve the in vitro embryo production in porcine.

Abstract: Molecular approaches have been used to determine metabolic substrates involved in the early embryonic processes to provide adequate culture conditions. To investigate the effect of modified Spirulina maxima pectin nanoparticles (MSmPNPs) on oocyte developmental competence, cumulus-oocyte complexes (COCs) retrieved from pig slaughterhouse ovaries were subjected to various concentrations of MSmPNPs $(0,2.5,5.0$, and $10 \mu \mathrm{g} / \mathrm{mL})$ during in vitro maturation (IVM). In comparison to the control, MSmPNPs-5.0, and MSmPNPs-10 groups, oocytes treated with $2.5 \mu \mathrm{g} / \mathrm{mL}$ MSmPNPs had significantly increased glutathione (GSH) levels and lower levels of reactive oxygen species (ROS). Following parthenogenetic activation, the MSmPNPs-2.5 group had a considerably higher maturation and cleavage rates, blastocyst development, total cell number, and ratio of inner cell mass/trophectoderm (ICM:TE) cells, when compared with those in the control and all other treated groups. Furthermore, similar findings were reported for the developmental competence of somatic cell nuclear transfer (SCNT)-derived embryos. Additionally, the relative quantification of POU5F1, DPPA2, and NDP52 mRNA transcript levels were significantly higher in the MSmPNPs-2.5 group than in the control and other treated groups. Taken together, the current findings suggest that MSmPNP treatment alleviates oxidative stress and enhances the developmental competence of porcine in vitro matured oocytes after parthenogenetic activation and SCNT.

Keywords: Spirulina maxima pectin; nanoparticles; porcine; embryos; development 


\section{Introduction}

Nanotechnology is a promising technique owing to its increasing applicability in economically areas, such as agriculture, industry, medicine, and public health $[1,2]$. Nanotechnology has been applied to improve animal production and health using different approaches $[3,4]$. Nanoparticles (NPs) have been used in disease diagnosis, drug administration, animal nutrition, reproduction, and food safety $[5,6]$. Because of their unique and distinctive physicochemical properties that differ significantly from bulk materials of the same composition, nanomaterials are being created for use in a wide range of commercial goods worldwide. There are some physicochemical properties give synthetic NPs features and a higher surface reactivity than their counterparts of the regular bulk materials; such as the minute size (increased surface area and size distribution), purity, surface reactivity, solubility, shape, and aggregation $[7,8]$.

NPs, such as lipid core NPs, supplemented during in vitro maturation (IVM), have previously been shown to improve oocyte quality, embryo cleavage, and blastocyst rates [9]. Furthermore, chitosan NPs efficiently prevent oxidative damage to oocytes [10]. In a previous study, we examined the effects of chitosan NP supplementation during IVM on porcine oocyte developmental competence and pre-implantation development in parthenogenetic and cloned embryos [11]. NPs containing various antioxidant materials can scavenge reactive oxygen species (ROS) and thus protect cellular molecules, such as lipids, proteins, and DNA, from oxidative stress, [11-13]. Therefore, many NPs are currently being used to improve the entire process of in vitro embryo production (IVP), such as gametes cryopreservation, oocyte in vitro maturation, and embryo culture [12,14-17], but some of these NPs exert toxic effects [18-25]. To overcome these toxic effects, plant-derived nanoparticles are biologically safe and applicable for improving the quality of oocytes and subsequent embryo development $[1,26]$.

Despite the chemical activation of in vitro fertilization (IVF), the therapeutic properties of plant extracts or their secondary derivatives on the regulation of folliculogenesis have been extensively studied under both in vitro and in vivo conditions [27]. In particular, plant polysaccharides have shown developmental competence of in vitro matured mouse oocytes by protective effects, such as reducing endoplasmic reticulum (ER) stress, preventing cell death, and activating both phosphatidylinositol 3-kinase (PI3K)/ Akt (protein kinase B, AKT) and mitogen-activated protein kinase (MAPK3/1) signaling [28].

Pectin is a cell wall ingredient in terrestrial plants, and feeds incorporated polysaccharides from livestock animals. The three major pectic polysaccharides are homogalacturonan (HG), rhamnogalacturonan-I (RG-I), and rhamnogalacturonan-II (RG-II) [29]. In clinical studies, pectin has been shown to have a broad range of immunomodulatory activities due to different molecular characteristics, such as source, extraction technique, degree of esterification (DE), degree of acetylation, and chemical modifications [30,31]. Among the other farm animals, pectin has shown a beneficial impact on pig nutrition and health contexts, which was performed in vivo, ex vivo, and in vitro studies [32]. The development of reproductive performance using crude extracts of microalgae has been widely discussed in livestock animals [33-36]. Microalgae Spirulina is a photosynthetic cyanobacterium that has been used to improve reproductive efficiency in in vivo bovine studies [33]. Recently, S. maxima-based pectin (SmP), and their modified two products namely, modified SmP (MSmP) and its nanoparticles (MSmPNPs) were investigated for different bioactivities in in vitro and in vivo studies [37-39]. Modification of SmP remarkably enhanced their functionality via physicochemical properties.

The production of cloned and transgenic pigs is a crucial step in xenotransplantation [40]. For successful production of these pigs, oxidative stress of recipient oocytes must be decreased during in vitro maturation (IVM), which can reprogram the gene-modified donor cells appropriately [41-43]. The goal of this study was to determine how MSmPNPs supplementation during IVM affected porcine oocyte developmental competence and pre-implantation development in parthenogenetic and cloned embryos. Consequently, this study was conducted to investigate the effects of MSmPNP supplementation on porcine 
oocyte maturation to reveal novel functional properties that enhance porcine IVP through parthenogenesis and SCNT. Intracellular glutathione (GSH) and ROS levels in the oocytes, pre-implantation embryo development, and the expression of a reprogramming-related gene were investigated.

\section{Materials and Methods}

2.1. Chemicals and Reagents

Unless otherwise stated, all chemicals and reagents were acquired from Sigma-Aldrich (St. Louis, MO, USA).

\subsection{Preparation of $M S m P N P S$}

S. maxima based MSmP was provided by the Jeju Marine Research Institute, Korea Institute of Ocean Science and Technology (KIOST), Jeju Special Self-Governing Province, Republic of Korea. The particle size of MSmP was further reduced by mechanical sonication. Briefly, MSmP was dissolved in deionized water and sonicated under an amplitude of 30\%, 10:10 s pulse at $4^{\circ} \mathrm{C}$ for $30 \mathrm{~min}$ (Sonics \& Materials. Inc. Newtown, CT, USA). Sonicated MSmP was centrifuged at $3500 \mathrm{rpm}$ for $15 \mathrm{~min}$ to collect MSmPNPs in the supernatant [39]. The average particle sizes of MSmp and MSmPNPs are $542.4 \mathrm{~nm}$ and $78.6 \mathrm{~nm}$, respectively. Zeta potential of MSmp and MSmPNPs are $-22.8 \mathrm{mV}$ and $-19.8 \mathrm{mV}$, respectively.

\subsection{Oocyte In Vitro Maturation and MSmPNPs Treatment}

The procedure for collecting porcine oocytes and IVM was performed according to our previous investigations [44]. Briefly, apparently healthy porcine ovaries were obtained within $4 \mathrm{~h}$ of slaughter at a local abattoir. Follicular fluid from 3-8 mm in diameter was aspirated into a $15 \mathrm{~mL}$ conical tube (Corning, Acton, MA, USA) using a $10 \mathrm{~mL}$ syringe and an 18-gauge needle. The fluid was rinsed with HEPES-buffered Tyrode's (TLH) medium (119 mM NaCl, 5 mM KCl, 25 mM HEPES buffer, 2 mM CaCl2, 2 mM MgCl2, 6 g/liter glucose, adjust $\mathrm{pH}$ to 7.4 with $\mathrm{NaOH})$ containing $0.05 \%(w / v)$ polyvinyl alcohol (PVA) after the oocytes settled for $5 \mathrm{~min}$. A stereomicroscope was used to select cumulus-oocyte complexes (COCs) with at least three layers of compact cumulus cells and homogenous ooplasm. COCs were washed three times with TLH-PVA and then with Dulbecco's phosphate-buffered saline (DPBS; Gibco, Life Technologies, Grand Island, NY, USA) modified with $0.4 \%$ bovine serum albumin (BSA) (mDPBS). The IVM medium consisted of TCM-199 (Gibco) supplemented with $10 \%(v / v)$ of porcine follicular fluid (pFF), $0.6 \mathrm{mM}$ cysteine, $0.91 \mathrm{mM}$ sodium pyruvate, $75 \mu \mathrm{g} / \mathrm{mL}$ kanamycin, $10 \mathrm{ng} / \mathrm{mL}$ epidermal growth factor (EGF), $1 \mu \mathrm{g} / \mathrm{mL}$ insulin, $10 \mathrm{IU} / \mathrm{mL}$ human chorionic gonadotrophin (hCG; Intervet International BV, Boxmeer, Holland), and $10 \mathrm{IU} / \mathrm{mL}$ pregnant mare serum gonadotrophin (PMSG). COCs were then incubated in IVM medium (50 COCs/500 $\mu \mathrm{L})$ at $39{ }^{\circ} \mathrm{C}$ in a humidified environment containing $5 \% \mathrm{CO}_{2}$. COCs were moved into hormone-free IVM medium after $22 \mathrm{~h}$ of incubation and cultured in four-well multi dishes (SPL, Pocheon, South Korea) for another $22 \mathrm{~h}$ under the same conditions. The oocytes in the control group were not supplemented to MSmPNPs during IVM, while the remaining oocytes were separated into three groups and treated with varied doses of MSmPNPs $(2.5,5.0$, and $10 \mu \mathrm{g} / \mathrm{mL}$ ) for the first $22 \mathrm{~h}$. Gentle pipetting of COCs in $0.5 \mathrm{mg} / \mathrm{mL}$ hyaluronidase solution (Catalog no. H7630, in PBS) in PBS was used to denude the in vitro matured oocytes. The oocyte morphology and appearance of the polar body in the perivitelline space were used to evaluate oocyte maturation, where oocytes in the metaphase II (MII) stage showed the first polar bodies with a dark distinct cytoplasm.

\subsection{Measurement of Intracellular GSH and ROS Levels}

The levels of intracellular GSH and ROS in in vitro-matured oocytes were measured as previously described $[11,45]$. The intensity of green fluorescence of 2,7-dichlorodihydrofluorescein diacetate was used to estimate intracellular ROS levels $\left(\mathrm{H}_{2} \mathrm{DCFDA}\right.$; Invitrogen Corporation, Carlsbad, CA, USA). After $44 \mathrm{~h}$ of IVM, intracellular GSH levels were measured using 
CellTracker ${ }^{\mathrm{TM}}$ Blue, which contains the blue fluorescent dye 4-chloromethyl-6,8-difluoro-7hydroxycoumarin $\left(\mathrm{CMF}_{2} \mathrm{HC}\right.$, Invitrogen Corporation). Twenty oocytes from each group were incubated in TLH-PVA supplemented with $10 \mu \mathrm{M} \mathrm{H}_{2}$ DCFDA and $10 \mu \mathrm{M}$ Cell Tracker Blue in the dark for $30 \mathrm{~min}$. Finally, oocytes were analyzed using an epifluorescence microscope with UV filters ( $\times 200$ magnification; Leica Application Suite X; Leica Microsystems, Wetzlar, Germany) (460 nm for ROS and $370 \mathrm{~nm}$ for GSH) (Figure 1a). The intensity of fluorescence was measured, and the photos were stored as TIFF graphic files for subsequent examination. The fluorescence intensity of the oocytes was standardized to that of the control oocytes using ImageJ software (version 1.41; National Institutes of Health, Bethesda, MD, USA).
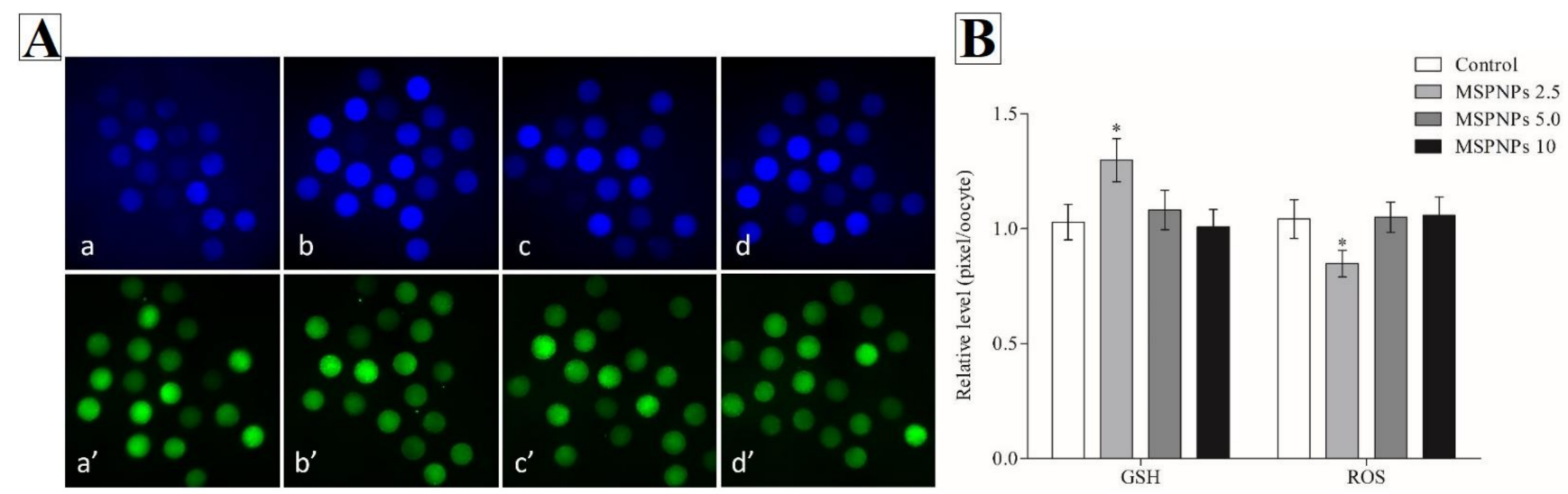

Figure 1. Evaluation of glutathione and reactive oxygen species of in vitro matured porcine oocytes at different concentrations of MSPNPs. (A) Oocytes were stained with (a-d) Cell Tracker Blue and $\left(\mathbf{a}^{\prime}-\mathbf{d}^{\prime}\right) 2^{\prime}, 7^{\prime}$-dichlorodihydrofluorescein diacetate (H2DCFDA) to detect intracellular levels of glutathione (GSH) and reactive oxygen species (ROS), respectively, whereas (a, $\left.\mathbf{a}^{\prime}\right)$ control and ( $\left.\mathbf{b}, \mathbf{b}^{\prime}\right)$ MSPNPs-2.5, (c, $\left.\mathbf{c}^{\prime}\right)$ MSPNPs-5.0, and (d, $\left.\mathbf{d}^{\prime}\right)$ MSPNPs-10 matured oocytes. (B) Effects on intracellular levels of GSH and ROS in vitro matured porcine oocytes. * Indicates that there is a significant difference in the GSH and ROS levels between each group $(p<0.05)$. GSH samples, $n=60$; ROS samples, $n=60$. The experiment was independently replicated three times.

\subsection{In Vitro Embryo Production}

Oocytes were parthenogenetically activated (PA) or used as karyoplasts for SCNT, with some modifications to our previous studies [45]. For PA, COCs were cultured in IVM medium $22 \mathrm{~h}$ and hormone-free IVM medium for $22 \mathrm{~h}$ and were then exposed to $0.1 \%(w / v)$ hyaluronidase. Cumulus cells were then and repeatedly pipetted gently. The mature, good-quality oocytes were parthenogenetically triggered with two $60 \mu \mathrm{sec}$ direct current (DC) pulses of $120 \mathrm{~V} / \mathrm{cm}$ in $280 \mathrm{mM}$ mannitol solution with $0.01 \mathrm{mM} \mathrm{CaCl}_{2}$ and $0.05 \mathrm{mM} \mathrm{MgCl} 2$ using a BTX 2001 Electro-cell Manipulator (BTX Harvard Apparatus, San Diego, CA, USA). For SCNT, a primary culture of donor cells was made from the kidney cells of an aborted cloned male pig at 50 days of gestation, which was chopped into small pieces and centrifuged three times. The culture medium comprised Dulbecco's Modified Eagle Medium (Gibco) with $10 \%(v / v)$ fetal bovine serum in a $60 \mathrm{~mm}$ tissue culture plate until a monolayer of cells was established with $70-80 \%$ confluency. For 48-72 h, donor cells in the G0/G1 stage of the cell cycle were synchronized by serum starvation. Donor cells were prepared by resuspending trypsinized cultured cells prior to nuclear transfer with $0.4 \%(w / v)$ BSA (TLH). Mature COCs were denuded as mentioned above. The denuded oocytes were then incubated in $5 \mu \mathrm{g} / \mathrm{mL}$ Hoechst 33342 medium for $15 \mathrm{~min}$. A $17 \mu \mathrm{m}$ beveled glass pipette was used to enucleate and extract polar bodies from metaphase II oocytes. A single cell was injected into the perivitelline space. In a $280 \mathrm{mM}$ mannitol solution with a low $\mathrm{Ca}^{+2}$ concentration $(0.001 \mathrm{mM})$, reconstructed SCNT oocytes were electrofused with two pulses of DC at $160 \mathrm{~V} / \mathrm{cm}$ for $40 \mu \mathrm{s}$, followed by an AC of $2 \mathrm{~V} / \mathrm{cm}$ for $2 \mathrm{~s}$, using a BTX 2001 Electro-cell Manipulator (Harvard Apparatus, San Diego, CA, USA). Presumptive zygotes were activated in a $280 \mathrm{mM}$ mannitol solution 
containing $0.01 \mathrm{mM} \mathrm{CaCl}_{2}$ and $0.05 \mathrm{mM} \mathrm{MgCl}_{2}$, after $30 \mathrm{~min}$ of fusing with two pulses of DC at $120 \mathrm{~V} / \mathrm{cm}$ for $60 \mu \mathrm{s}$. Both PA and SCNT embryos were post-activated for $4 \mathrm{~h}$ with $10 \mu \mathrm{g} / \mathrm{mL}$ cytochalasin B and 6-dimethylaminopurine after electrical activation [46]. Activated oocytes were then washed three times in an in vitro culture medium (porcine zygote medium-5; IFP, Higashine, Yamagata, Japan) and 20 oocytes cultured in $25 \mu \mathrm{L}$ droplets, covered with pre-warmed mineral oil, and the embryos were then cultured at $39{ }^{\circ} \mathrm{C}$ in a humidified atmosphere $\left(5 \% \mathrm{O}_{2}, 5 \% \mathrm{CO}_{2}\right.$, and $\left.90 \% \mathrm{~N}_{2}\right)$. Cleavage and blastocyst formation were measured on days two and six for embryo development and blastocyst formation, respectively. Cell numbers were counted on day six to determine the total cell number, the inner cell mass (ICM), and trophectoderm (TE) expression in accordance with the differential staining methodology described in our previous studies [45].

\subsection{Analysis of mRNA Transcript Expression by Relative Quantitative Real-Time Polymerase Chain Reaction ( $q R T-P C R$ )}

A relative quantitative polymerase chain reaction (qRT-PCR) was used to analyze the mRNA expression of genes involved in nuclear reprogramming and pluripotency (POU5F1, NDP52, and DPPA2). The primer sequences are listed in Table 1. TRIzol reagent (Invitrogen Corporation) was used to extract total RNA from six-day-old blastocysts from the untreated (control) and treated groups [47]. Reverse transcription 2X RT Pre-Mix (BioFACT Co., Ltd., Daejeon, Korea) and oligo dT primers were used to generate complementary DNA (cDNA) from $300 \mathrm{ng}$ of total RNA (Neoprobe). The absorbance of a diluted RNA samples was measured at 260 and $280 \mathrm{~nm}$ by NanoDrop Spectrophotometer (Thermo Fisher Scientific, Pittsburgh, PA, USA). Each RNA sample consisted of $0.5 \mu \mathrm{g} / \mu \mathrm{L}$. The following reaction settings were used for RT-qPCR: denaturation at $95^{\circ} \mathrm{C}$ for $15 \mathrm{~min}$ and $20 \mathrm{~s}$, followed by 40 cycles of annealing and extension at $60^{\circ} \mathrm{C}$ for $40 \mathrm{~s}$ (BIOFACT Co., Ltd., Daejeon, Korea). The expression of each target gene was measured in comparison to that of the internal control gene ( $\beta$-actin). The threshold cycle $(\mathrm{Ct})$ at a constant fluorescence intensity was used for relative quantification of gene expression using the $2^{-(\Delta \mathrm{Ct} \text { sample }-\Delta \mathrm{Ct} \text { control) }}$ method [48]. Each value was normalized to that of $\beta$-actin to determine the normalized arbitrary values for each gene.

Table 1. S Specific primers used for gene expression analysis by qPCR.

\begin{tabular}{|c|c|c|c|c|}
\hline Genes & Gene Full Name & Sequences $\left(5^{\prime}-3^{\prime}\right)$ & Product Size (bp) & NCBI Accession No. \\
\hline$\beta$-actin & Beta actin & $\begin{array}{l}\text { F: CCC TGG AGA GCT ACG AG } \\
\text { R: TCC TTC CTG ATG TCC ACG TC }\end{array}$ & 172 & XM_003124280.5 \\
\hline POU5F1 & POU class 5 homeobox 1 & $\begin{array}{l}\text { F: AGT GAG AGG CAA CCT GGA GA } \\
\text { R: TCG TTG CGA ATA GTC ACT GC }\end{array}$ & 166 & XM_021097869.1 \\
\hline NDP52 & Nuclear domain 10 protein & $\begin{array}{l}\text { F: TGC TGA GTT ACA TGG GTC TGG } \\
\text { R: ACC AAG GTC TGA TTT GCA GGT }\end{array}$ & 182 & XM_003131552.4 \\
\hline DPPA2 & $\begin{array}{l}\text { Developmental pluripotency } \\
\text { associated } 2\end{array}$ & $\begin{array}{l}\text { F: TGA GAG AGG GGA AAA GAC CAA } \\
\text { R: TGG CAG AAA GGT CTC AAC AGA }\end{array}$ & 151 & XM_003358822.4 \\
\hline
\end{tabular}

\subsection{Experimental Design}

The effects of supplementing porcine oocytes with or without $0,2.5,5.0$, and $10 \mu \mathrm{g} / \mathrm{mL}$ MSmPNPs during IVM were examined in Experiment 1. Intracellular GSH and ROS levels were measured after $44 \mathrm{~h}$ of IVM. The effects of MSmPNP treatment during IVM of oocytes were investigated on the developmental competence of parthenogenetic and cloned embryos in Experiment 2. The effect of MSmPNP supplementation on the number of parthenogenetic and cloned blastocysts was investigated in Experiment 3. The effects of MSmPNP supplementation during IVM reprogramming-related genes (POU5F1, DPPA2, and NDP52) and the control gene ( $\beta$-actin) in the cloned blastocysts acquired in Experiment 2 were investigated in Experiment 4. 


\subsection{Statistical Analysis}

Origin software (version 8.1; OriginLab Corporation, Northampton, MA, USA) was used to analyze the data. All data are reported as mean \pm standard error of the mean (SEM), with a probability $(p)$ value of $<0.05$, regarded as statistically significant. The generalized linear model technique and one-way analysis of variance (ANOVA) were used to assess data on oocyte maturation, blastocyst development rates in PA and cloned embryos, cell number, GSH, ROS, and gene expression. Duncan's multiple range test was used to establish significance.

\section{Results}

\subsection{GSH and ROS Intracellular Levels Treated with/without MSmPNPS}

Following oocyte maturation, the levels of intracellular GSH and ROS were measured. Mature oocytes in the MSmPNPs-2.5 group had significantly higher intracellular GSH levels $(p<0.05))$ compared to the control, MSmPNPs-5.0 and MSmPNPs-10 groups, (Figure 1b). Furthermore, intracellular ROS levels in the MSmPNPs-2.5 group were considerably lower $(p<0.05))$ than those in the control and other MSmPNP-treated groups.

\subsection{The Effect of MSmPNPs on the Developmental Competence of PA Embryos}

To improve the maturation, cleavage, and blastocyst development rate, varying amounts of MSmPNPs were added to in vitro maturation media. The results showed that the MSmPNPs-2.5 group significantly increased $(p<0.05)$ maturation $(91.0 \pm 1.0 \%$ vs. $86.5 \pm 1.3 \%$ vs. $80.0 \pm 0.8 \%$ vs. $83.5 \pm 1.8 \%$, respectively) compared to MSmPNPs-5.0, MSmNPS-10, and control groups (Table 2). The MSmPNPS-2.5 group displayed a significantly increased cleavage $(90.5 \pm 0.8 \%$ vs. $86.4 \pm 1.3 \%$ vs. $80.3 \pm 1.1 \%$ vs. $85.1 \pm 1.3 \%$, respectively) and blastocysts rate ( $34.5 \pm 1.4 \%$ vs. $29.6 \pm 1.7 \%$ vs. $24.9 \pm 1.1 \%$ vs. $29.2 \pm 1.0 \%$, respectively) than other groups.

Table 2. Effect of in vitro maturation of porcine oocytes with different concentrations of MSmPNPs on the in vitro development rate of PA embryos.

\begin{tabular}{cccccc}
\hline \multirow{2}{*}{ Conc. of MSmPNPs $(\mu \mathrm{g} / \mathbf{m L})$} & \multirow{2}{*}{ No. of COCs } & No. of Matured Oocytes (\%) & \multicolumn{3}{c}{ No. of Embryos (Mean \pm SEM) } \\
\cline { 4 - 6 } & & & Cultured & Cleaved (\%) $^{\text {Blastocyst (\%) }}$ \\
\hline 0 (Control) & 200 & $167(83.5 \pm 1.8)^{\mathrm{b}}$ & 161 & $137(85.1 \pm 1.3)^{\mathrm{b}}$ & $47(29.2 \pm 1.0)^{\mathrm{b}}$ \\
2.5 & 200 & $182(91.0 \pm 1.0)^{\mathrm{a}}$ & 168 & $152(90.5 \pm 0.8)^{\mathrm{a}}$ & $58(34.5 \pm 1.4)^{\mathrm{a}}$ \\
5.0 & 200 & $173(86.5 \pm 1.3)^{\mathrm{b}}$ & 162 & $140(86.4 \pm 1.3)^{\mathrm{a}} \mathrm{b}$ & $48(29.6 \pm 1.7)^{\mathrm{a}, \mathrm{b}}$ \\
10 & 200 & $160(80.0 \pm 0.8)^{\mathrm{b}}$ & 157 & $126(80.3 \pm 1.1)^{\mathrm{c}}$ & $39(24.9 \pm 1.1)^{\mathrm{b}}$ \\
\hline
\end{tabular}

$\mathrm{a}, \mathrm{b}$ Values in the same column with different superscript letters are significantly different $(p<0.05)$. Number of replicates $(n=4)$.

\subsection{MSmPNPs Effects on Cell Number of PA Embryos}

Table 3 shows a comparison of the total number of cells, ICM, TE, and ICM:TE ratio in PA embryos between the MSmPNP-treated groups and the control group. Compared to the control group $(42.8 \pm 1.2 \%)$, the MSmPNPs-2.5 group ( $48.7 \pm 1.4 \%)$ showed a significant $(p<0.05)$ increase in the total cell number than the MSmPNP $-5.0(44.0 \pm 1.1 \%)$ and MSmPNPS-10 (40.2 $\pm 1.0 \%$ ) groups. These results revealed that higher concentrations of MSmPNPs reduced the total cell number, the TE, ICM, and ICM:TE, while MSmPNPs-2.5 groups showed a significantly increased in these parameters. 
Table 3. The effects of in vitro maturation of porcine oocytes with different concentrations of MSmPNPs on different cell number of in vitro PA blastocysts.

\begin{tabular}{|c|c|c|c|c|}
\hline \multirow{2}{*}{ Conc. of MSmPNPs ( $\mu \mathrm{g} / \mathrm{mL})$} & \multicolumn{3}{|c|}{ No. of Cells (Mean \pm SEM) } & \multirow{2}{*}{ Ratio (\%) of ICM: TE } \\
\hline & Total Cells & TE (\%) & ICM (\%) & \\
\hline 0 (Control) & $42.8 \pm 1.2^{\mathrm{b}, \mathrm{c}}$ & $33.8(78.7 \pm 1.0)^{\mathrm{a}}$ & $9.0(21.3 \pm 1.0)^{b}$ & $27.9 \pm 1.7^{b}$ \\
\hline 2.5 & $48.7 \pm 1.4^{\mathrm{a}}$ & $36.6(74.8 \pm 0.8)^{b}$ & $12.0(25.2 \pm 0.8)^{a}$ & $34.5 \pm 1.4^{\mathrm{a}}$ \\
\hline 5.0 & $44.0 \pm 1.1^{b}$ & $33.4(75.6 \pm 0.7)^{b, c}$ & $10.7(24.4 \pm 0.7)^{\mathrm{a}, \mathrm{b}}$ & $32.8 \pm 1.2^{\mathrm{a}, \mathrm{b}}$ \\
\hline 10 & $40.2 \pm 1.0^{c}$ & $32.0(79.6 \pm 0.9)^{\mathrm{a}}$ & $8.2(20.4 \pm 0.9)^{b}$ & $26.1 \pm 1.5^{b}$ \\
\hline
\end{tabular}

${ }^{\mathrm{a}-\mathrm{c}}$ Values in the same column with different superscript letters are significantly different $(p<0.05)$. Number of replicates $(n=4)$.

\subsection{MSmPNPs Effects on the Developmental Competence of Cloned Embryos}

Cloned embryos produced from MSmPNPs-2.5-treated oocytes had higher development rates than the other groups $(p<0.05)$ (Table 4). Oocytes in the MSmPNPs-2.5 group had significantly higher in maturation $(89.5 \pm 1.8 \%)$, cleavage $(88.5 \pm 1.6 \%)$, and blastocysts rates $(31.1 \pm 1.1 \%)$ than those in the control $(83.0 \pm 1.5,84.7 \pm 1.0$, and $24.8 \pm 0.9 \%$, respectively), MSmPNPs-5.0 (86.5 $\pm 1.3,87.4 \pm 2.1$, and $25.9 \pm 0.9 \%$, respectively), and MSmPNPs-10 (80.5 $\pm 1.4,82.6 \pm 1.3$, and $22.7 \pm 1.4 \%$, respectively) treated groups.

Table 4. Effect of in vitro maturation of porcine oocytes with different concentrations of MSmPNPs on in vitro development rate of SCNT embryos.

\begin{tabular}{|c|c|c|c|c|c|}
\hline \multirow{2}{*}{ Conc. of MSmPNPs ( $\mu \mathrm{g} / \mathrm{mL})$} & \multirow{2}{*}{ No. of COCs } & \multirow{2}{*}{ No. of Matured Oocytes (\%) } & \multicolumn{3}{|c|}{ No. of Embryos (Mean \pm SEM) } \\
\hline & & & Cultured & Cleaved (\%) & Blastocyst (\%) \\
\hline 0 (Control) & 200 & $166(83.0 \pm 1.5)^{b}$ & 137 & $116(84.7 \pm 1.0)$ & $34(24.8 \pm 0.9)^{b}$ \\
\hline 2.5 & 200 & $179(89.5 \pm 1.8)^{\text {a }}$ & 148 & $131(88.5 \pm 1.6)$ & $46(31.1 \pm 1.1)^{\mathrm{a}}$ \\
\hline 5.0 & 200 & $173(86.5 \pm 1.3)^{b}$ & 143 & $125(87.4 \pm 2.1)$ & $37(25.9 \pm 0.9)^{b}$ \\
\hline 10 & 200 & $161(80.5 \pm 1.4)^{\mathrm{b}}$ & 132 & $109(82.6 \pm 1.3)$ & $30(22.7 \pm 1.4)^{b}$ \\
\hline
\end{tabular}

a,b Values in the same column with different superscript letters are significantly different $(p<0.05)$. Number of replicates $(n=4)$.

\subsection{MSmPNPs Effects on Cloned Cell Number}

Table 5 compares the total cell number, ICM, TE expression, and ICM:TE ratio of cloned embryos. In the MSmPNPs-2.5-treated oocytes group, the overall cell number $(48.9 \pm 1.5 \%)$, TE $(74.0 \pm 0.9 \%)$, ICM $(26.0 \pm 0.9 \%)$, and ICM:TE $(35.7 \pm 1.8 \%)$ were significantly higher $(p<0.05)$ than those in the control and other treated groups.

Table 5. Effect of in vitro maturation of porcine oocytes with different concentrations of MSmPNPs on different cell number of SCNT blastocysts.

\begin{tabular}{ccccc}
\hline \multirow{2}{*}{ Conc. of MSmPNPs $(\mu \mathrm{g} / \mathrm{mL})$} & \multicolumn{3}{c}{ No. of Cells (Mean \pm SEM) } & \multirow{2}{*}{ Ratio (\%) of ICM: TE } \\
\cline { 2 - 4 } & Total Cells & TE (\%) & ICM (\%) & \\
\hline 0 (Control) & $41.9 \pm 1.9^{\mathrm{b}, \mathrm{c}}$ & $33.2(78.7 \pm 1.2)^{\mathrm{a}}$ & $8.8(21.3 \pm 1.2)^{\mathrm{b}}$ & $27.9 \pm 2.2^{\mathrm{b}}$ \\
2.5 & $48.9 \pm 1.5^{\mathrm{a}}$ & $36.4(74.0 \pm 0.9)^{\mathrm{b}}$ & $12.5(26.0 \pm 0.9)^{\mathrm{a}}$ & $35.7 \pm 1.8^{\mathrm{a}}$ \\
5.0 & $44.4 \pm 1.0^{\mathrm{b}}$ & $34.6(77.7 \pm 1.0)^{\mathrm{a}}$ & $9.7(22.3 \pm 1.0)^{\mathrm{b}}$ & $29.0 \pm 1.7^{\mathrm{b}}$ \\
10 & $39.2 \pm 2.5^{\mathrm{c}}$ & $31.0(78.5 \pm 1.1)^{\mathrm{a}}$ & $8.2(21.5 \pm 1.1)^{\mathrm{b}}$ & $27.6 \pm 1.7^{\mathrm{b}}$ \\
\hline
\end{tabular}

${ }^{a-c}$ Values in the same column with different superscript letters are significantly different $(p<0.05)$. Number of replicates $(n=4)$.

\subsection{MSmPNPs Effects on Reprogramming-Related Gene Expression}

qRT-PCR analysis of cloned blastocyst mRNA transcripts supported the benefits of MSmPNPs-2.5 and MSmPNPs-5.0 supplementation during porcine oocyte IVM on the development of resultant embryos. The expression levels of the reprogramming-related genes, POU5F1, DPPA2, and NDP52, were significantly higher in cloned blastocysts produced from MSmPNPs-2.5-and MSmPNPs-5.0-treated oocytes than in MSmPNPs-10 and untreated control blastocysts. Moreover, the relative expression levels of these genes in the MSmPNPs-2.5 group were significantly higher than those in the other groups (Figure 2). 


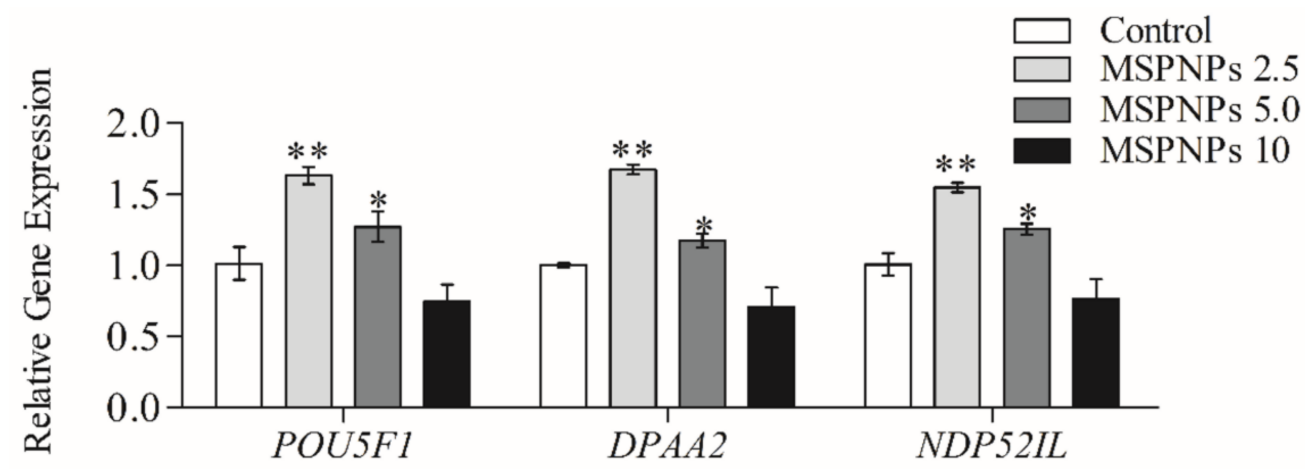

Figure 2. Relative expression of POU5F1, DPPA2, and NDP52 mRNA transcripts in cloned blastocysts obtained from oocytes supplemented with varying concentrations of MSmPNPs $(0,2.5,5.0$, and $10 \mu \mathrm{g} / \mathrm{mL}$ ) in maturation media. Each sample consisted of five blastocysts and three times replicate. * Indicates that there is a significant difference in mRNA values between each group $(p<0.05)$.

** Indicates that there is a significant difference in mRNA values at $p<0.01$.

\section{Discussion}

Given the importance of genetically modified pigs in biomedical research, an ideal environment for porcine preimplantation embryo development in vitro is required. Interdisciplinary investigations between biology and nanotechnology may solve some problems associated with biological applications, particularly IVP in pigs [2]. To provide proper culture conditions during IVP, omics technologies are being applied to discover the metabolic substrates that are activated during early embryonic processes. Therefore, combining omics and nanotechnology to develop a suitable culture medium for improving porcine IVP would increase the number of pigs that are valid for transgenic technologies. However, the use of NPs showed a considerable increase in the risk of toxic effects to the animals, because they can cross the placental barrier, leading to embryo damage [18,49].

In this experiment, we used MSmPNPs as a component to improve porcine IVM and subsequent preimplantation embryo development. Recent study showed that the biliprotein phycocyanin, derived from Spirulina platensis, enhanced the developmental competence of the oocytes from obese female mice [50]. Additionally, IVM supplementation with phycocyanin improved the embryonic development of parthenogenetic and cloned embryos in porcine [51]. The natural polysaccharide pectin has gained increasing attention owing to its physicochemical and biomedical activities [52]. It exerts antioxidant activity in experimental, in vitro free radical scavenging [52-57], and in vivo models [58]. Furthermore, Zhang et al. reported that lower doses $(5-25 \mu \mathrm{M})$ of naturally occurring phenolic compounds (rosmarinic acid) attenuated intracellular ROS levels in porcine oocytes and cumulus cells during IVM [59]. Moreover, low doses $(100 \mu \mathrm{M})$ of the polyphenolic compound procyanidin, which is derived from plant sources, also decreased ROS production and apoptosis, while promoting the quality of oocytes and PA embryo development [60]. Therefore, it is ideal to investigate the anti-oxidative effects of MSmPNPs on the critical stage of IVP in porcine IVM and subsequent embryo development.

The results showed that MSmPNPs mediate the reduction in ROS levels and increase in GSH, which are favorable conditions during IVM [61,62]. Although ROS are generated during different cellular metabolic processes, in vitro-matured oocytes are more sensitive to oxidative stress [63]. Therefore, alleviating such negative effects of oxidative stress will enhance mitochondrial function and improve oocyte maturation and cleavage capabilities [64]. Therefore, we hypothesized that pectin-like biomaterials extracted from Spirulina maxima may have positive anti-oxidative and free radical scavenging effects during oocyte IVM.

Previous studies have shown that SmP and SmPNPs enhance wound healing [17], disease resistance, and stress tolerance [65] by reducing oxidative stress. There is no previous report on the use of Spirulina pectins to improve the quality of developing oocytes. Thus, to our knowledge, this is the first study to explore the effects of marine S. maxima pectin on oocyte maturation and developmental competence in oocytes in vitro. According 
to our findings, the optimum concentration of MSmPNPs to effectively neutralize IVMderived ROS in porcine oocytes was $2.5 \mu \mathrm{g} / \mathrm{mL}$. Compared to the control and other treatment groups, matured oocytes in the MSmPNPs 2.5-treated group had significantly higher intracellular GSH levels and lower ROS levels. Increased intracellular GSH levels have been linked to improved cytoplasmic maturation, embryonic development, and offspring production [3]. Furthermore, GSH levels are important for maintaining the cellular redox; a lack of GSH can lead to apoptotic stimuli in mature ovarian follicles [66,67]. In the present study, $2.5 \mu \mathrm{g} / \mathrm{mL}$ of MSmPNPs effectively reduced intracellular ROS levels and enhanced the non-enzymatic antioxidant (GSH) level in oocytes and cumulus cells at the end of IVM.

Interestingly, IVM medium containing $2.5 \mu \mathrm{g} / \mathrm{mL}$ of MSmPNPs markedly improved the quality of porcine developmental competence of PA and SCNT embryos, as indicated by enhanced hatching and total cell counts of blastocysts. Moreover, qRT-PCR analysis further confirmed the upregulated expression pattern of selected reprogramming and pluripotency-related genes (POU5F1, DPAA2, and NDP52) at lower doses of MSmPNPs ( 2.5 and $5 \mu \mathrm{g} / \mathrm{mL}$ ). From the given results, it appears that increasing the concentrations of the MSmPNPs tends to be toxic to the IVM environment and the IVM conditions favors the reduced and optimal concentration, which is $2.5 \mu \mathrm{g} / \mathrm{mL}$. PPOU5F1 (or OCT4) is known as a master gene for pluripotency, as its expression controls early embryonic stem cells and development [68]. DPPA2 (or PESCRG1) acts as a transcription factor, is involved in the maintenance of the active epigenetic status of these genes, and maintains the pluripotency of stem cells [69-71]. Moreover, NDP52 (or CALCOCO2) is an OCT4-related gene, and its expression is limited to the pluripotent cells of the early embryo and the germline (blastocysts, epiblasts, and purified primordial germ cells) and regulates embryonic stem cell pluripotency and early blastocyst development [72,73]. Collectively, the activation of POU5F1, DPPA2, and NDP52 improved the proper reprogramming of donor nuclei after reactivation of genes [74]. Overall, the results confirmed that excess ROS neutralization by antioxidant properties of MSmPNPs could effectively improve oocyte maturation and subsequent embryonic developmental competence of cloned and parthenogenetic embryos. Further investigations are required to study the effects on in vitro fertilization-derived embryos. This finding provides novel IVM conditions through the integration of innovative nanomaterials from marine Spirulina.

\section{Conclusions}

Oocytes treated with MSmPNPs during IVM resulted in a higher rate of pre-implantation porcine parthenogenetic and cloned embryos development. The highest impacts were seen at a supplementation of $2.5 \mu \mathrm{g} / \mathrm{mL}$ MSmPNPs and had a constructive impact on oocyte quality and embryonic development and embryo eminence by increasing the levels of intracellular GSH while reducing ROS levels, as well as increasing the expression of the pluripotency-associated genes POU5F1, DPPA2, and NDP52 in the resultant blastocysts. This finding provides novel IVM conditions through the integration of innovative nanomaterials from marine Spirulina.

Author Contributions: Conceptualization, P.-K.R., M.D.Z., D.-H.K., and J.C.; methodology, P.-K.R., X.F., and G.K.; investigation, P.-K.R., G.K., and M.D.Z.; data curation, P.-K.R., A.-Y.Q., B.-M.T., G.S., I.M.S., and J.C.; writing—original draft preparation, P.-K.R., B.-M.T., S.B., S.-L.E., I.M.S., and M.D.Z.; writing-review and editing, P.-K.R., A.-Y.Q., M.D.Z., D.-H.K., I.M.S., and J.C.; project administration, M.D.Z. and J.C.; funding acquisition, D.-H.K. and J.C. All authors have read and agreed to the published version of the manuscript.

Funding: This research was supported by a grant from the Korea Health Technology R\&D Project through the Korea Health Industry Development Institute, funded by the Ministry of Health and Welfare, Republic of Korea (grant number: HI13C0954), and from a research funds (PE99922) of Jeju Marine Research Institute, Korea Institute of Ocean Science and Technology (KIOST), Republic of Korea. 
Institutional Review Board Statement: All experiments were approved and performed under the guidelines of the Institutional Animal Care and Use Committee of Chungnam National University (IACUC approval no.: CNU-00624).

Acknowledgments: We thank all the members of our laboratory for their technical support and helpful discussions.

Conflicts of Interest: The authors declare no conflict of interest.

\section{References}

1. Saadeldin, I.M.; Khalil, W.A.; Alharbi, M.G.; Lee, S.H. The Current Trends in Using Nanoparticles, Liposomes, and Exosomes for Semen Cryopreservation. Animals 2020, 10, 2281. [CrossRef]

2. Lucas, C.G.; Chen, P.R.; Seixas, F.K.; Prather, R.S.; Collares, T. Applications of omics and nanotechnology to improve pig embryo production in vitro. Mol. Reprod. Dev. 2019, 86, 1531-1547. [CrossRef]

3. Neculai-Valeanu, A.S.; Ariton, A.M.; Mădescu, B.M.; Rîmbu, C.M.; Creangă, Ş. Nanomaterials and Essential Oils as Candidates for Developing Novel Treatment Options for Bovine Mastitis. Animals 2021, 11, 1625. [CrossRef] [PubMed]

4. Abo-Al-Ela, H.G.; El-Kassas, S.; El-Naggar, K.; Abdo, S.E.; Jahejo, A.R.; Al Wakeel, R.A. Stress and immunity in poultry: Light management and nanotechnology as effective immune enhancers to fight stress. Cell Stress Chaperones 2021, 26, 457-472. [CrossRef]

5. Abdelnour, S.A.; Alagawany, M.; Hashem, N.M.; Farag, M.R.; Alghamdi, E.S.; Hassan, F.U.; Bilal, R.M.; Elnesr, S.S.; Dawood, M.A.O.; Nagadi, S.A.; et al. Nanominerals: Fabrication Methods, Benefits and Hazards, and Their Applications in Ruminants with Special Reference to Selenium and Zinc Nanoparticles. Animals 2021, 11, 1916. [CrossRef]

6. Hashem, N.M.; Gonzalez-Bulnes, A. Nanotechnology and Reproductive Management of Farm Animals: Challenges and Advances. Animals 2021, 11, 1932. [CrossRef] [PubMed]

7. Guisbiers, G.; Mejía-Rosales, S.; Leonard Deepak, F. Nanomaterial Properties: Size and Shape Dependencies. J. Nanomater. 2012, 2012, 1-2. [CrossRef]

8. Jeevanandam, J.; Barhoum, A.; Chan, Y.S.; Dufresne, A.; Danquah, M.K. Review on nanoparticles and nanostructured materials: History, sources, toxicity and regulations. Beilstein J. Nanotechnol. 2018, 9, 1050-1074. [CrossRef]

9. Lucas, C.G.; Remiao, M.H.; Bruinsmann, F.A.; Lopes, I.A.R.; Borges, M.A.; Feijo, A.L.S.; Basso, A.C.; Pohlmann, A.R.; Guterres, S.S.; Campos, V.F.; et al. High doses of lipid-core nanocapsules do not affect bovine embryonic development in vitro. Toxicol. Vitr. 2017, 45, 194-201. [CrossRef] [PubMed]

10. Abdel-Halim, B.R. Protective effect of Chitosan nanoparticles against the inhibitory effect of linoleic acid supplementation on maturation and developmental competence of bovine oocytes. Theriogenology 2018, 114, 143-148. [CrossRef] [PubMed]

11. Roy, P.K.; Qamar, A.Y.; Fang, X.; Kim, G.; Bang, S.; De Zoysa, M.; Shin, S.T.; Cho, J. Chitosan nanoparticles enhance developmental competence of in vitro-matured porcine oocytes. Reprod. Domest. Anim. 2021, 56, 342-350. [CrossRef]

12. Bakhtari, A.; Nazari, S.; Alaee, S.; Kargar-Abarghouei, E.; Mesbah, F.; Mirzaei, E.; Molaei, M.J. Effects of Dextran-Coated Superparamagnetic Iron Oxide Nanoparticles on Mouse Embryo Development, Antioxidant Enzymes and Apoptosis Genes Expression, and Ultrastructure of Sperm, Oocytes and Granulosa Cells. Int. J. Fertil. Steril. 2020, 14, 161-170. [CrossRef]

13. Shehata, A.M.; Salem, F.M.S.; El-Saied, E.M.; Abd El-Rahman, S.S.; Mahmoud, M.Y.; Noshy, P.A. Zinc Nanoparticles Ameliorate the Reproductive Toxicity Induced by Silver Nanoparticles in Male Rats. Int. J. Nanomed. 2021, 16, 2555-2568. [CrossRef]

14. Abbasi, Y.; Hajiaghalou, S.; Baniasadi, F.; Mahabadi, V.P.; Ghalamboran, M.R.; Fathi, R. $\mathrm{Fe}_{3} \mathrm{O}_{4}$ magnetic nanoparticles improve the vitrification of mouse immature oocytes and modulate the pluripotent genes expression in derived pronuclear-stage embryos. Cryobiology 2021, 100, 81-89. [CrossRef] [PubMed]

15. El-Naby, A.-s.A.-H.H.; Ibrahim, S.; Hozyen, H.F.; Sosa, A.S.A.; Mahmoud, K.G.M.; Farghali, A.A. Impact of nano-selenium on nuclear maturation and genes expression profile of buffalo oocytes matured in vitro. Mol. Biol. Rep. 2020, 47, 8593-8603. [CrossRef] [PubMed]

16. Ariu, F.; Bogliolo, L.; Pinna, A.; Malfatti, L.; Innocenzi, P.; Falchi, L.; Bebbere, D.; Ledda, S. Cerium oxide nanoparticles (CeO 2 NPs) improve the developmental competence of in vitro-matured prepubertal ovine oocytes. Reprod. Fertil. Dev. 2017, $29,1046$. [CrossRef] [PubMed]

17. Li, W.; Zhou, X.; Dai, J.; Zhang, D.; Liu, B.; Wang, H.; Xu, L. Effect of hydroxyapatite nanoparticles on MII-stage porcine oocytes vitrification and the study of its mechanism. J. Biomed. Eng. = Shengwu Yixue Gongchengxue Zazhi 2013, 30, 789-793.

18. Huang, C.H.; Yeh, J.M.; Chan, W.H. Hazardous impacts of silver nanoparticles on mouse oocyte maturation and fertilization and fetal development through induction of apoptotic processes. Environ. Toxicol. 2018, 33, 1039-1049. [CrossRef]

19. Santacruz-Márquez, R.; González-De los Santos, M.; Hernández-Ochoa, I. Ovarian toxicity of nanoparticles. Reprod. Toxicol. 2021, 103, 79-95. [CrossRef]

20. Lin, Y.H.; Zhuang, S.X.; Wang, Y.L.; Lin, S.; Hong, Z.W.; Liu, Y.; Xu, L.; Li, F.P.; Xu, B.H.; Chen, M.H.; et al. The effects of graphene quantum dots on the maturation of mouse oocytes and development of offspring. J. Cell. Physiol. 2019, 234, 13820-13831. [CrossRef]

21. Taylor, U.; Tiedemann, D.; Rehbock, C.; Kues, W.A.; Barcikowski, S.; Rath, D. Influence of gold, silver and gold-Silver alloy nanoparticles on germ cell function and embryo development. Beilstein J. Nanotechnol. 2015, 6, 651-664. [CrossRef] 
22. Karimipour, M.; Zirak Javanmard, M.; Ahmadi, A.; Jafari, A. Oral administration of titanium dioxide nanoparticle through ovarian tissue alterations impairs mice embryonic development. Int. J. Reprod. Biomed. 2018, 16, 397-404. [CrossRef]

23. Lei, R.; Bai, X.; Chang, Y.; Li, J.; Qin, Y.; Chen, K.; Gu, W.; Xia, S.; Zhang, J.; Wang, Z.; et al. Effects of Fullerenol Nanoparticles on Rat Oocyte Meiosis Resumption. Int. J. Mol. Sci. 2018, 19, 699. [CrossRef]

24. Wang, R.; Song, B.; Wu, J.; Zhang, Y.; Chen, A.; Shao, L. Potential adverse effects of nanoparticles on the reproductive system. Int. J. Nanomed. 2018, 13, 8487-8506. [CrossRef] [PubMed]

25. Liu, J.; Zhao, Y.; Ge, W.; Zhang, P.; Liu, X.; Zhang, W.; Hao, Y.; Yu, S.; Li, L.; Chu, M.; et al. Oocyte exposure to ZnO nanoparticles inhibits early embryonic development through the $\gamma-\mathrm{H} 2 \mathrm{AX}$ and NF-kB signaling pathways. Oncotarget 2017, 8, 42673-42692. [CrossRef] [PubMed]

26. Ismail, A.A.; Abdel-Khalek, A.E.; Khalil, W.A.; Yousif, A.I.; Saadeldin, I.M.; Abomughaid, M.M.; El-Harairy, M.A. Effects of mint, thyme, and curcumin extract nanoformulations on the sperm quality, apoptosis, chromatin decondensation, enzyme activity, and oxidative status of cryopreserved goat semen. Cryobiology 2020, 97, 144-152. [CrossRef] [PubMed]

27. Mbemya, G.T.; Vieira, L.A.; Canafistula, F.G.; Pessoa, O.D.L.; Rodrigues, A.P.R. Reports on in vivo and in vitro contribution of medicinal plants to improve the female reproductive function. Reprod. Clim. 2017, 32, 109-119. [CrossRef]

28. Yang, L.; Lei, L.; Zhao, Q.; Gao, Z.; Xu, X. Lycium barbarum polysaccharide improves the development of mouse oocytes vitrified at the germinal vesicle stage. Cryobiology 2018, 85, 7-11. [CrossRef]

29. Willats, W.G.; McCartney, L.; Mackie, W.; Knox, J.P. Pectin: Cell biology and prospects for functional analysis. Plant Mol. Biol. 2001, 47, 9-27. [CrossRef]

30. de Moura, F.A.; Macagnan, F.T.; Dos Santos, L.R.; Bizzani, M.; de Oliveira Petkowicz, C.L.; da Silva, L.P. Characterization and physicochemical properties of pectins extracted from agroindustrial by-products. J. Food Sci. Technol. 2017, 54, $3111-3117$. [CrossRef]

31. Fracasso, A.F.; Perussello, C.A.; Carpiné, D.; Petkowicz, C.L.O.; Haminiuk, C.W.I. Chemical modification of citrus pectin: Structural, physical and rheologial implications. Int. J. Biol. Macromol. 2018, 109, 784-792. [CrossRef] [PubMed]

32. Wiese, M. The potential of pectin to impact pig nutrition and health: Feeding the animal and its microbiome. FEMS Microbiol. Lett. 2019, 366, fnz029. [CrossRef] [PubMed]

33. Mizera, A.; Kuczaj, M.; Szul, A. Impact of the Spirulina maxima extract addition to semen extender on bovine sperm quality. Ital. J. Anim. Sci. 2019, 18, 601-607. [CrossRef]

34. Barkallah, M.; Slima, A.B.; Elleuch, F.; Fendri, I.; Pichon, C.; Abdelkafi, S.; Baril, P. Protective Role of Spirulina platensis Against Bifenthrin-Induced Reprotoxicity in Adult Male Mice by Reversing Expression of Altered Histological, Biochemical, and Molecular Markers Including MicroRNAs. Biomolecules 2020, 10, 753. [CrossRef]

35. Lee, A.V.; You, L.; Oh, S.Y.; Li, Z.; Fisher-Heffernan, R.E.; Regnault, T.R.H.; de Lange, C.F.M.; Huber, L.; Karrow, N.A. Microalgae supplementation to late gestation sows and its effects on the health status of weaned piglets fed diets containing high- or low-quality protein sources. Vet. Immunol. Immunopathol. 2019, 218, 109937. [CrossRef]

36. Senosy, W.; Kassab, A.Y.; Mohammed, A.A. Effects of feeding green microalgae on ovarian activity, reproductive hormones and metabolic parameters of Boer goats in arid subtropics. Theriogenology 2017, 96, 16-22. [CrossRef] [PubMed]

37. Edirisinghe, S.L.; Dananjaya, S.H.S.; Nikapitiya, C.; Liyanage, T.D.; Lee, K.A.; Oh, C.; Kang, D.H.; De Zoysa, M. Novel pectin isolated from Spirulina maxima enhances the disease resistance and immune responses in zebrafish against Edwardsiella piscicida and Aeromonas hydrophila. Fish Shellfish Immunol. 2019, 94, 558-565. [CrossRef] [PubMed]

38. Edirisinghe, S.L.; Rajapaksha, D.C.; Nikapitiya, C.; Oh, C.; Lee, K.-A.; Kang, D.-H.; De Zoysa, M. Spirulina maxima derived marine pectin promotes the in vitro and in vivo regeneration and wound healing in zebrafish. Fish Shellfish Immunol. 2020, 107, 414-425. [CrossRef]

39. Chandrarathna, H.; Liyanage, T.D.; Edirisinghe, S.L.; Dananjaya, S.H.S.; Thulshan, E.H.T.; Nikapitiya, C.; Oh, C.; Kang, D.H.; De Zoysa, M. Marine Microalgae, Spirulina maxima-Derived Modified Pectin and Modified Pectin Nanoparticles Modulate the Gut Microbiota and Trigger Immune Responses in Mice. Mar. Drugs 2020, 18, 175. [CrossRef]

40. Park, D.S.; Kim, S.; Koo, D.-B.; Kang, M.-J. Current Status of Production of Transgenic Livestock by Genome Editing Technology. J. Anim. Reprod. Biotechnol. 2019, 34, 148-156. [CrossRef]

41. Roy, P.K.; Qamar, A.Y.; Fang, X.; Hassan, B.M.S.; Cho, J. Effects of cobalamin on meiotic resumption and developmental competence of growing porcine oocytes. Theriogenology 2020, 154, 24-30. [CrossRef]

42. Lin, T.; Lee, J.E.; Kang, J.W.; Oqani, R.K.; Cho, E.S.; Kim, S.B.; Il Jin, D. Melatonin supplementation during prolonged in vitro maturation improves the quality and development of poor-quality porcine oocytes via anti-oxidative and anti-apoptotic effects. Mol. Reprod. Dev. 2018, 85, 665-681. [CrossRef] [PubMed]

43. Kim, J.-W.; Park, H.-J.; Yang, S.-G.; Koo, D.-B. Anti-oxidative effects of exogenous ganglioside GD1a and GT1b on embryonic developmental competence in pigs. J. Anim. Reprod. Biotechnol. 2020, 35, 347-356. [CrossRef]

44. Cho, J.; Kim, G.; Qamar, A.Y.; Fang, X.; Roy, P.K.; Tanga, B.M.; Bang, S.; Kim, J.K.; Galli, C.; Perota, A.; et al. Improved efficiencies in the generation of multigene-modified pigs by recloning and using sows as the recipient. Zygote 2021, 1-8. [CrossRef]

45. Roy, P.K.; Qamar, A.Y.; Tanga, B.M.; Fang, X.; Kim, G.; Bang, S.; Cho, J. Enhancing Oocyte Competence With Milrinone as a Phosphodiesterase 3A Inhibitor to Improve the Development of Porcine Cloned Embryos. Front. Cell Dev. Biol. 2021, 9, 647616. [CrossRef] [PubMed] 
46. Roy, P.K.; Kim, G.; Fang, X.; Hassan, B.; Soysa, M.D.; Shin, S.T.; Cho, J.K. Optimization of post-activation systems to improve the embryonic development in porcine parthenogenesis and somatic cell nuclear transfer. J. Embryo Transf. 2017, 32, 95-104. [CrossRef]

47. Kim, G.; Roy, P.K.; Fang, X.; Hassan, B.M.; Cho, J. Improved preimplantation development of porcine somatic cell nuclear transfer embryos by caffeine treatment. J. Vet. Sci. 2019, 20, e31. [CrossRef] [PubMed]

48. Livak, K.J.; Schmittgen, T.D. Analysis of Relative Gene Expression Data Using Real-Time Quantitative PCR and the $2^{-\Delta \Delta C T}$ Method. Methods 2001, 25, 402-408. [CrossRef] [PubMed]

49. Wang, Z.; Wang, Z. Nanoparticles induced embryo-fetal toxicity. Toxicol. Ind. Health 2020, 36, 181-213. [CrossRef]

50. Wen, X.; Han, Z.; Liu, S.-J.; Hao, X.; Zhang, X.-J.; Wang, X.-Y.; Zhou, C.-J.; Ma, Y.-Z.; Liang, C.-G. Phycocyanin Improves Reproductive Ability in Obese Female Mice by Restoring Ovary and Oocyte Quality. Front. Cell Dev. Biol. 2020, 8, 1208. [CrossRef]

51. Liang, S.; Guo, J.; Jin, Y.X.; Yuan, B.; Zhang, J.B.; Kim, N.H. C-Phycocyanin supplementation during in vitro maturation enhances pre-implantation developmental competence of parthenogenetic and cloned embryos in pigs. Theriogenology 2018, 106, 69-78. [CrossRef]

52. Wathoni, N.; Yuan Shan, C.; Yi Shan, W.; Rostinawati, T.; Indradi, R.B.; Pratiwi, R.; Muchtaridi, M. Characterization and antioxidant activity of pectin from Indonesian mangosteen (Garcinia mangostana L.) rind. Heliyon 2019, 5, e02299. [CrossRef] [PubMed]

53. Smirnov, V.V.; Golovchenko, V.V.; Vityazev, F.V.; Patova, O.A.; Selivanov, N.Y.; Selivanova, O.G.; Popov, S.V. The Antioxidant Properties of Pectin Fractions Isolated from Vegetables Using a Simulated Gastric Fluid. J. Chem. 2017, 2017, 1-10. [CrossRef]

54. Hosseini Abari, A.; Amini Rourani, H.; Ghasemi, S.M.; Kim, H.; Kim, Y.-G. Investigation of antioxidant and anticancer activities of unsaturated oligo-galacturonic acids produced by pectinase of Streptomyces hydrogenans YAM1. Sci. Rep. 2021, $11,8491$. [CrossRef]

55. Ogutu, F.O.; Mu, T.-H. Ultrasonic degradation of sweet potato pectin and its antioxidant activity. Ultrason. Sonochem. 2017, 38, 726-734. [CrossRef] [PubMed]

56. Chen, R.; Jin, C.; Tong, Z.; Lu, J.; Tan, L.; Tian, L.; Chang, Q. Optimization extraction, characterization and antioxidant activities of pectic polysaccharide from tangerine peels. Carbohydr. Polym. 2016, 136, 187-197. [CrossRef]

57. Kang, H.J.; Jo, C.; Kwon, J.H.; Son, J.H.; An, B.J.; Byun, M.W. Antioxidant and Cancer Cell Proliferation Inhibition Effect of Citrus Pectin-Oligosaccharide Prepared by Irradiation. J. Med. Food 2006, 9, 313-320. [CrossRef]

58. Li, T.; Li, S.; Dong, Y.; Zhu, R.; Liu, Y. Antioxidant activity of penta-oligogalacturonide, isolated from haw pectin, suppresses triglyceride synthesis in mice fed with a high-fat diet. Food Chem. 2014, 145, 335-341. [CrossRef]

59. Zhang, Y.; Guo, J.; Nie, X.W.; Li, Z.Y.; Wang, Y.M.; Liang, S.; Li, S. Rosmarinic acid treatment during porcine oocyte maturation attenuates oxidative stress and improves subsequent embryo development in vitro. Peer] 2019, 7, e6930. [CrossRef]

60. Gao, W.; Jin, Y.; Hao, J.; Huang, S.; Wang, D.; Quan, F.; Ren, W.; Zhang, J.; Zhang, M.; Yu, X. Procyanidin B1 promotes in vitro maturation of pig oocytes by reducing oxidative stress. Mol. Reprod. Dev. 2021, 88, 55-66. [CrossRef] [PubMed]

61. Choi, J.-Y.; Kang, J.-T.; Park, S.-J.; Kim, S.-J.; Moon, J.-H.; Saadeldin, I.M.; Jang, G.; Lee, B.-C. Effect of 7,8-Dihydroxyflavone as an Antioxidant on In Vitro Maturation of Oocytes and Development of Parthenogenetic Embryos in Pigs. J. Reprod. Dev. 2013, 59, 450-456. [CrossRef] [PubMed]

62. Kang, J.-T.; Moon, J.H.; Choi, J.-Y.; Park, S.J.; Kim, S.J.; Saadeldin, I.M.; Lee, B.C. Effect of Antioxidant Flavonoids (Quercetin and Taxifolin) on In Vitro Maturation of Porcine Oocytes. Asian-Australas. J. Anim. Sci. 2016, 29, 352-358. [CrossRef] [PubMed]

63. Guerin, P. Oxidative stress and protection against reactive oxygen species in the pre-implantation embryo and its surroundings. Hum. Reprod. Update 2001, 7, 175-189. [CrossRef] [PubMed]

64. Somfai, T.; Kaneda, M.; Akagi, S.; Watanabe, S.; Haraguchi, S.; Mizutani, E.; Dang-Nguyen, T.Q.; Geshi, M.; Kikuchi, K.; Nagai, T. Enhancement of lipid metabolism with L-carnitine during in vitro maturation improves nuclear maturation and cleavage ability of follicular porcine oocytes. Reprod. Fertil. Dev. 2011, 23, 912-920. [CrossRef]

65. Rajapaksha, D.C.; Edirisinghe, S.L.; Nikapitiya, C.; Dananjaya, S.; Kwun, H.J.; Kim, C.H.; Oh, C.; Kang, D.H.; De Zoysa, M. Spirulina maxima Derived Pectin Nanoparticles Enhance the Immunomodulation, Stress Tolerance, and Wound Healing in Zebrafish. Mar. Drugs 2020, 18, 556. [CrossRef] [PubMed]

66. Devine, P.J.; Perreault, S.D.; Luderer, U. Roles of Reactive Oxygen Species and Antioxidants in Ovarian Toxicity1. Biol. Reprod. 2012, 86, 1-10. [CrossRef]

67. Circu, M.L.; Yee Aw, T. Glutathione and apoptosis. Free Radic. Res. 2009, 42, 689-706. [CrossRef]

68. Kim, S.J.; Koo, O.J.; Park, H.J.; Moon, J.H.; da Torre, B.R.; Javaregowda, P.K.; Kang, J.T.; Park, S.J.; Saadeldin, I.M.; Choi, J.Y.; et al. Oct4 overexpression facilitates proliferation of porcine fibroblasts and development of cloned embryos. Zygote 2014, 23, 704-711. [CrossRef]

69. Sato, Y.; Kobayashi, H.; Higuchi, T.; Shimada, Y.; Era, T.; Kimura, S.; Eto, Y.; Ida, H.; Ohashi, T. Disease modeling and lentiviral gene transfer in patient-specific induced pluripotent stem cells from late-onset Pompe disease patient. Mol. Ther. Methods Clin. Dev. 2015, 2, 15023. [CrossRef]

70. Eckersley-Maslin, M.A. Keeping your options open: Insights from Dppa2/4 into how epigenetic priming factors promote cell plasticity. Biochem. Soc. Trans. 2020, 48, 2891-2902. [CrossRef]

71. Lim, P.S.L.; Meshorer, E. Dppa2 and Dppa4 safeguard bivalent chromatin in order to establish a pluripotent epigenome. Nat. Struct. Mol. Biol. 2020, 27, 685-686. [CrossRef] [PubMed] 
72. Hellweg, C.E.; Shinde, V.; Srinivasan, S.P.; Henry, M.; Rotshteyn, T.; Baumstark-Khan, C.; Schmitz, C.; Feles, S.; Spitta, L.F.; Hemmersbach, R.; et al. Radiation Response of Murine Embryonic Stem Cells. Cells 2020, 9, 650. [CrossRef] [PubMed]

73. Bortvin, A.; Eggan, K.; Skaletsky, H.; Akutsu, H.; Berry, D.L.; Yanagimachi, R.; Page, D.C.; Jaenisch, R. Incomplete reactivation of Oct4-related genes in mouse embryos cloned from somatic nuclei. Development 2003, 130, 1673-1680. [CrossRef]

74. You, J.; Lee, J.; Kim, J.; Park, J.; Lee, E. Post-fusion treatment with MG132 increases transcription factor expression in somatic cell nuclear transfer embryos in pigs. Mol. Reprod. Dev. 2010, 77, 149-157. [CrossRef] [PubMed] 